\title{
SARS-CoV-2 Virus - Host Interaction: Currently Available Structures and Implications of Variant Emergence on Infectivity and Immune Response
}

\author{
Luís Queirós-Reis ${ }^{1}$, Priscilla Gomes da Silva ${ }^{1,2,3}{ }^{\mathbb{C}}$, José Gonçalves ${ }^{4}{ }^{\circledR}$, Andrea Brancale ${ }^{5}{ }^{(0)}$, Marcella Bassetto ${ }^{6}(\mathbb{C})$ \\ and João R. Mesquita ${ }^{1,2, *(1)}$ \\ 1 Abel Salazar Institute of Biomedical Sciences (ICBAS), University of Porto, 4050-313 Porto, Portugal; \\ up201205115@up.pt (L.Q.-R.); priscilla@ua.pt (P.G.d.S.) \\ 2 Epidemiology Research Unit (EPIunit), Institute of Public Health, University of Porto, \\ 4050-091 Porto, Portugal \\ 3 LEPABE—Laboratory for Process Engineering, Environment, Biotechnology and Energy, \\ Faculty of Engineering, University of Porto, 4200-465 Porto, Portugal \\ 4 Institute of Sustainable Processes, University of Valladolid, 47011 Valladolid, Spain; zemcg5@gmail.com \\ 5 Cardiff School of Pharmacy and Pharmaceutical Sciences, Cardiff University, Cardiff CF10 3NB, UK; \\ brancalea@cardiff.ac.uk \\ 6 Department of Chemistry, Faculty of Science and Engineering, Swansea University, Swansea SA2 8PP, UK \\ marcella.bassetto@swansea.ac.uk \\ * Correspondence: jrmesquita@icbas.up.pt
}

\section{check for} updates

Citation: Queirós-Reis, L.; Gomes da Silva, P.; Gonçalves, J.; Brancale, A.; Bassetto, M.; Mesquita, J.R. SARS-CoV-2 Virus-Host Interaction: Currently Available Structures and Implications of Variant Emergence on Infectivity and Immune Response. Int. J. Mol. Sci. 2021, 22, 10836. https://doi.org/10.3390/ ijms221910836

Academic Editor: Luisa Barzon

Received: 3 September 2021

Accepted: 1 October 2021

Published: 7 October 2021

Publisher's Note: MDPI stays neutral with regard to jurisdictional claims in published maps and institutional affiliations.

Copyright: (c) 2021 by the authors. Licensee MDPI, Basel, Switzerland. This article is an open access article distributed under the terms and conditions of the Creative Commons Attribution (CC BY) license (https:/ / creativecommons.org/licenses/by/ $4.0 /)$.

\begin{abstract}
Coronavirus disease 19, or COVID-19, is an infection associated with an unprecedented worldwide pandemic caused by the Severe Acute Respiratory Syndrome Coronavirus 2 (SARSCoV-2), which has led to more than 215 million infected people and more than 4.5 million deaths worldwide. SARS-CoV-2 cell infection is initiated by a densely glycosylated spike (S) protein, a fusion protein, binding human angiotensin converting enzyme 2 (hACE2), that acts as the functional receptor through the receptor binding domain (RBD). In this article, the interaction of hACE2 with the RBD and how fusion is initiated after recognition are explored, as well as how mutations influence infectivity and immune response. Thus, we focused on all structures available in the Protein Data Bank for the interaction between SARS-CoV-2 S protein and hACE2. Specifically, the Delta variant carries particular mutations associated with increased viral fitness through decreased antibody binding, increased RBD affinity and altered protein dynamics. Combining both existing mutations and mutagenesis studies, new potential SARS-CoV-2 variants, harboring advantageous $\mathrm{S}$ protein mutations, may be predicted. These include mutations S13I and W152C, decreasing antibody binding, N460K, increasing RDB affinity, or Q498R, positively affecting both properties.
\end{abstract}

Keywords: SARS-CoV-2; Spike protein; hACE2; protein structures

\section{Introduction}

Coronavirus disease 19, or COVID-19, is an infection associated with an unprecedented global pandemic caused by the severe acute respiratory syndrome coronavirus 2 (SARS-CoV-2), which resulted in more than 215 million infected people and more than 4.5 million deaths [1-3]. SARS-CoV-2 was first identified in December 2019 in Wuhan, Hubei province of China, in individuals exposed at a seafood/wet market and was successfully isolated and sequenced in January 2020 [1]. Genetic evidence suggests that the virus originates from animals, particularly bats, as SARS-CoV-2 has $96 \%$ sequence identity to a strain found in bats (BatCov RaTG13), possibly having pangolins, minks, turtles, or snakes as the intermediate host $[1,4]$.

Coronaviruses (CoVs) are a group of RNA viruses belonging to the subfamily Orthocoronaviridae that cause disease in a variety of domestic and wild animals (e.g. porcine, 
bovine, feline and avian, and bat and whale strains) [5]. A defining characteristic in all $\mathrm{CoVs}$ is the crown-like viral particle, from which their name is derived [6,7]. It consists of three major structural proteins (spike, membrane, and envelope), that protrude from the viral envelope and have a critical function in cell recognition and fusion [6]. Additionally, the nucleocapsid (protein N) binds and stabilizes the viral genome (Figure 1) [8].

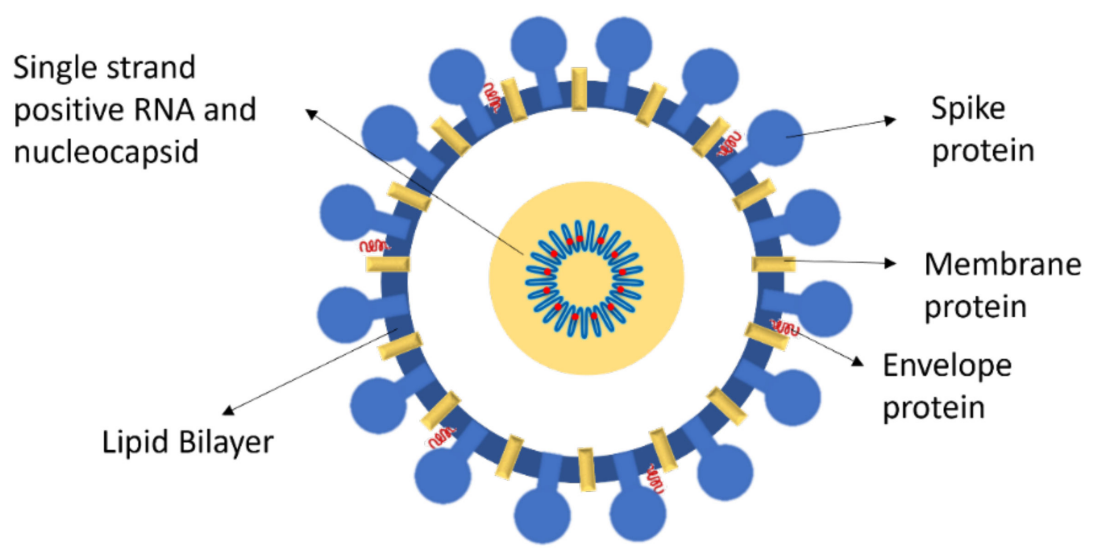

Figure 1. Representation of SARS-CoV-2 main structural proteins.

Furthermore, they have the second largest RNA viral genome, a positive sense genome of single-stranded RNA (+ssRNA), with an average size of $30 \mathrm{~kb}$ [9]. Importantly, CoVs have a large genome with a high mutation rate (one nucleotide per 1000 to 10,000 nucleotides replicated), associated with the RNA dependent RNA polymerase, and a random template switching during RNA duplications, that causes a high frequency of homologous RNA recombination [5]. These characteristics are responsible for the special plasticity of CoVs when it comes to accommodating and modifying genes, explaining the broad range of hosts infected by them [5].

Taken together, these factors have led to a diversity of strains and genotypes highly adaptable to new hosts and ecological niches, causing major zoonotic outbreaks [5].

SARS-CoV-2 is transmitted via aerosols or droplets, typically within one metre or in poorly ventilated and/or crowded indoor settings, and possibly by touching contaminated and eyes, nose, or mouth, with both symptomatic and asymptomatic patients being the main source of infection $[1,10]$. The immune response appears to be characteristic of each individual, with a unique collection of antibodies (Abs) and varying efficacy of viral neutralization potency observed [11].

Over time, numerous SARS-CoV-2 variants have been reported, differing by one or more mutations from the first virus sequenced, the so-called original virus variant, which corresponds to the Wuhan strain [12]. Some of these have been classified as variants of concern (VOC), defined by their features, such as increased transmissibility, virulence and disease severity, decreased $\mathrm{Ab}$ neutralization or vaccine efficiency and/or errors in current detection protocols [13-15]. The list of variants of concern is frequently updated according to new information, by the Centers for Disease Control and Prevention (CDC), World Health Organization or the European Centre for Disease Prevention and Control (ECDC) [14-18]. Additionally, some variants are classified as variants of interest (VOI), characterized by mutations with predicted negative features, although with insufficient evidence, by limited prevalence or epidemiological data suggesting an emerging risk to public health [14-16]. Variants can also be de-escalated, particularly if they cease to circulate, if, despite circulating, they have a negligible effect on the epidemiological situation or if scientific evidence shows no concerning features (Table 1) [14]. 
Table 1. List of variants currently or in the past considered as variants of concern or variants of interest.

\begin{tabular}{|c|c|c|c|c|c|c|c|}
\hline $\begin{array}{l}\text { WHO } \\
\text { Label }\end{array}$ & $\begin{array}{l}\text { Pango } \\
\text { Lineage }\end{array}$ & Origin & Infectivity & $\begin{array}{l}\text { Effects on Immune } \\
\text { Response }\end{array}$ & Clinical Relevance & $\begin{array}{c}\text { Current } \\
\text { Classification } \\
\text { (CDC/WHO/ECDC) }\end{array}$ & References \\
\hline Alpha & B.1.1.7 & $\begin{array}{l}\text { United Kingdom } \\
\text { Sep-2020 }\end{array}$ & $\begin{array}{l}50 \% \text { increased } \\
\text { transmission }\end{array}$ & Minimal impact & Increased severity & VOC I VOC I DE & {$[14,16]$} \\
\hline Beta & B.1.351 & $\begin{array}{l}\text { South Africa } \\
\text { May-2020 }\end{array}$ & $\begin{array}{l}50 \% \text { increased } \\
\text { transmission }\end{array}$ & $\begin{array}{c}\text { Significant reduction in } \\
\text { neutralization }\end{array}$ & $\begin{array}{c}\text { Reduced susceptibility to } \\
\text { treatment }\end{array}$ & VOC I VOC I VOC & [19-22] \\
\hline Gamma & P.1 & $\begin{array}{l}\text { Japan/Brazil } \\
\text { Nov-2020 }\end{array}$ & $\begin{array}{l}\text { Potential increased } \\
\text { transmissibility }{ }^{1}\end{array}$ & $\begin{array}{l}\text { Significant reduced } \\
\text { neutralization }\end{array}$ & $\begin{array}{c}\text { Significantly reduced } \\
\text { susceptibility to treatment }\end{array}$ & VOC I VOC I VOC & [22-25] \\
\hline Delta & B.1.617.2 & $\begin{array}{l}\text { India } \\
\text { Oct-2020 }\end{array}$ & $\begin{array}{l}\text { Increased } \\
\text { transmissibility }\end{array}$ & $\begin{array}{l}\text { Significant reduction in } \\
\text { neutralization }\end{array}$ & $\begin{array}{l}\text { Reduced susceptibility to } \\
\text { treatment }\end{array}$ & VOC I VOC I VOC & {$[14,16]$} \\
\hline Epsilon & B.1.427/B.1.429 & $\begin{array}{c}\text { USA } \\
\text { Sep-2020 }\end{array}$ & Unclear & Reduced neutralization & No effect reported & NA | NA | DE & [14] \\
\hline Zeta & P.2 & $\begin{array}{c}\text { Brazil } \\
\text { Nov-2020 }\end{array}$ & No effect reported & $\begin{array}{l}\text { Potential reduced } \\
\text { neutralization }^{1}\end{array}$ & No effect reported & NA | NA | DE & [14] \\
\hline Eta & B.1.525 & $\begin{array}{l}\text { Nigeria } \\
\text { Dec-2020 }\end{array}$ & No effect reported & $\begin{array}{l}\text { Potential reduced } \\
\text { neutralization }\end{array}$ & $\begin{array}{c}\text { Potential reduced } \\
\text { susceptibility to treatment }{ }^{1}\end{array}$ & VOI | VOI | DE & [14] \\
\hline Theta & P.3 & $\begin{array}{l}\text { Philippines } \\
\text { Jan-2021 }\end{array}$ & $\begin{array}{l}\text { Potential increased } \\
\text { transmissibility }{ }^{1}\end{array}$ & $\begin{array}{l}\text { Potential reduced } \\
\text { neutralization }\end{array}$ & No effect reported & NA I NA | DE & [14] \\
\hline Iota & B.1.526 & $\begin{array}{c}\text { USA } \\
\text { Dec-2020 }\end{array}$ & No effect reported & Reduced neutralization & $\begin{array}{c}\text { Potential reduced } \\
\text { susceptibility to treatment }{ }^{1}\end{array}$ & VOI | VOI | DE & {$[14,16]$} \\
\hline Kappa & B.1.617.1 & $\begin{array}{c}\text { India } \\
\text { Oct-2020 }\end{array}$ & $\begin{array}{l}\text { Potential increased } \\
\text { transmissibility }^{1}\end{array}$ & $\begin{array}{l}\text { Potential reduced } \\
\text { neutralization }\end{array}$ & $\begin{array}{c}\text { Potential reduced } \\
\text { susceptibility to treatment }\end{array}$ & VOI | VOI | DE & {$[14,16]$} \\
\hline Lambda & C.37 & $\begin{array}{c}\text { Peru } \\
\text { Dec-2020 }\end{array}$ & $\begin{array}{l}\text { Potential increased } \\
\text { transmissibility }\end{array}$ & $\begin{array}{c}\text { Significantly reduction in } \\
\text { neutralization }\end{array}$ & No effect reported & NA | VOI | VOI & {$[14,26]$} \\
\hline $\mathrm{Mu}$ & B.1.621 & $\begin{array}{l}\text { Colombia } \\
\text { Jan-2021 }\end{array}$ & $\begin{array}{l}\text { Potential increased } \\
\text { transmissibility }{ }^{1}\end{array}$ & Reduced neutralization & No effect reported & NA | VOI | VOI & [14] \\
\hline
\end{tabular}

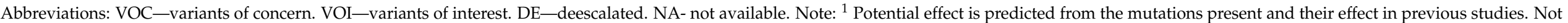
directly observed in the variant. 


\section{Glycoprotein: Cell Recognition and Infection}

As with all CoVs, SARS-CoV-2 cell infection is initiated by a densely glycosylated spike (S) protein, a trimeric class I fusion protein that binds to human angiotensin converting enzyme 2 (hACE2), acting as the functional receptor [1]. hACE2 expression is ubiquitous in the human body and although the degree of expression varies between organs, it is at its highest in type II alveolar epithelial cells in the lungs, which indicates the primary target for the virus [27]. In addition, hACE2 expression is also high in other tissues, such as myocardial cells, kidney and enterocytes, which explains less common symptoms as well as the multiorgan injuries observed in severe cases [27].

In general, the $S$ protein exists in two main conformations, prefusion and post-fusion, requiring major structural rearrangements after recognition to promote cell fusion [28]. The S protein consists of two subunits (S1 and S2) responsible for cell recognition and membrane fusion, respectively [1]. Although S1 and S2 are originally covalently bound, there is a cleavage site between the subunits, where host serine proteases, such as furin, transmembrane protease serine protease 2 (TMPRSS2) or cathepsin L, cleave the protein $[1,11,28]$. Notably, TMPRSS2 is co-expressed with hACE2 in nasal epithelial cells, lungs and bronchial branches [11]. When the S1 and S2 subunits are cleaved, the protein is activated and can undergo the necessary conformational changes to achieve the post-fusion conformation and consequently enable cell infection (Figure 2) [1,28].

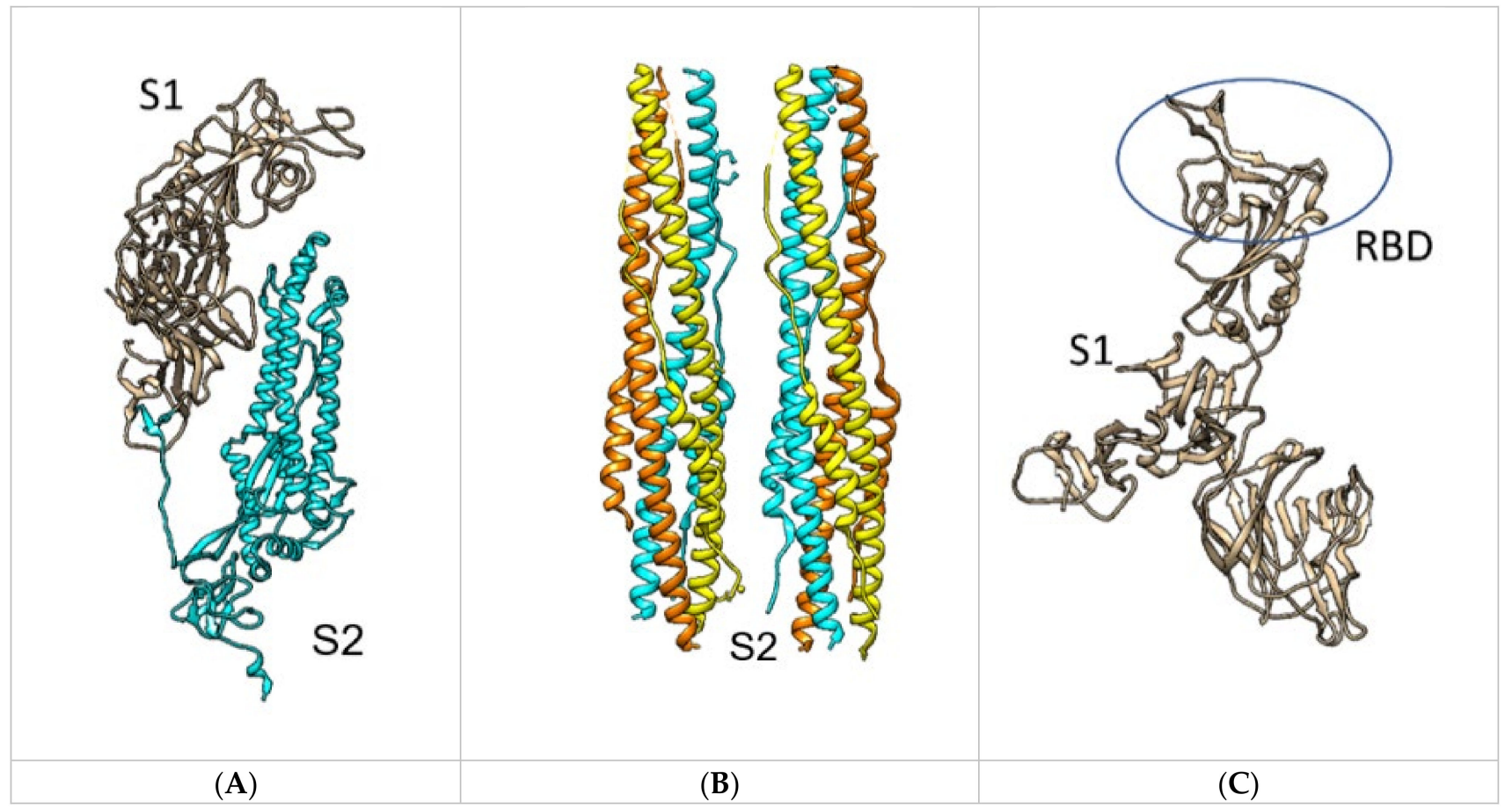

Figure 2. (A) Single chain in trimeric spike protein with subunit S1 (Tan) and S2 (Cyan) in 7A94. (B) Post-fusion conformation of all S2 units in the trimeric spike in 6LXT. (C) S1 subunit, with the RBD highlighted in 7A94 [29].

The S1 subunit formed of the N-terminal domain (NTD) and a receptor binding domain (RBD) that directly interacts with hACE2. Therefore, it is considered a key target for antivirals and neutralizing Abs, accounting for $90 \%$ of the neutralizing activity in convalescent sera [1,30-32]. Despite the low percentage of NTD-directed Abs, some are still potent inhibitors [32]. The NTD and two neighbouring regions, namely a $\beta$-hairpin (residues 140-158) and a loop (residues 245-264), are collectively termed an antigenic supersite, where NTD directed Abs bind [32]. The NTD-directed Abs neutralizing activity is due to both viral entry blocking and also limiting cell-to-cell spread of the virus [32].

Regarding the RBD, it can be further divided in two structural domains, a highly conserved core, and a variable external subdomain that binds hACE2 [1]. 
Subunit S2 contains two heptad repeats, a transmembrane domain, a cytoplasmic tail, a central helix, and the fusion peptide that is critical for the main function of S2 of merging the host and viral cell membranes (Figure 2) [31]. Additionally, N-linked glycans are extensively present along the molecule and are essential in proper folding [1,31].

Even if the $S$ protein is activated through the cleavage process, the RBDs can still be inaccessible for interaction [28]. Each RBD can be either down (closed conformation), inaccessible for interaction, or up (open conformation). The open conformation is the necessary state for recognition, with the recognition motifs protruding from the $\mathrm{S}$ protein (Figure 3) [1,28].

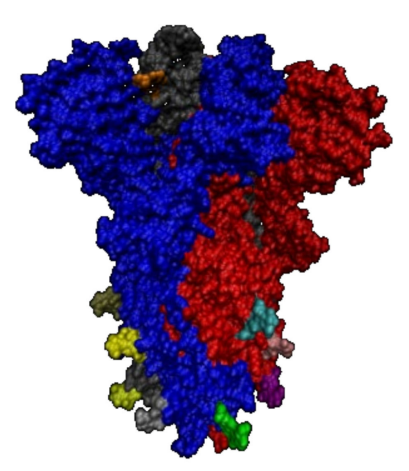

(A)

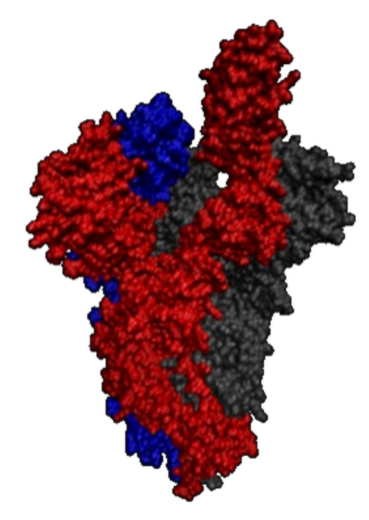

(B)

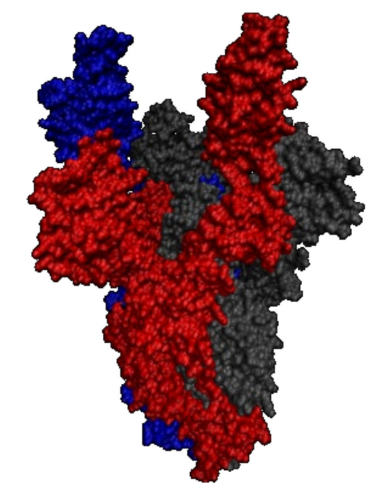

(C)

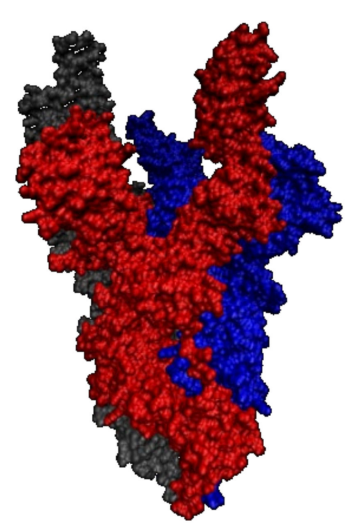

(D)

Figure 3. Spike protein conformations, with each spike monomer is represented by a colour (blue, red, gray). (A) All RBD down (PBD 6VVX) (B) 1 RBD up (PDB 7A94) (C) 2 RBD up (PDB 7A97) (D) All RBD up (PDB 7A98) [33].

To engage the host cell receptor, the RBD undergoes hinge-like conformational changes, transiently switching from a down conformation, to a less stable up conformation. Each RBD is capable of individually changing its conformation (Figure 3) [28]. When ACE2 interacts with the RBD, it binds tightly and stabilizes the up conformation [1,34].

In this review, the interaction of hACE2 with the RBD is explored, namely the important contacts between proteins and how this interaction can be modulated to increase affinity or reduce $\mathrm{Ab}$ binding. Additionally, we will also try to elucidate how the binding of hACE2 affects S1/S2 interaction, the importance of this interaction in cell fusion and how mutations can influence infectivity and immune response. This information may be important to predict or explain the changes in infectivity or immune response for new variants, which has been studied for the SARS-CoV-2 Delta variant, currently becoming the most prevalent variant worldwide [35].

A total of 37 structures were selected, three of which are complexes that, despite involving the SARS-CoV-2 S protein, also have an Ab or non-human ACE2, and therefore would not reliably represent the critical interactions between the virus and the human protein. The remaining structures can be broadly divided into two categories: studying the RBD-hACE2 interaction or full spike protein behaviour, focusing on the conformation changes from recognition to fusion (Figure 4) [21]. Furthermore, some structures also have hACE2 in a complex with broad neutral amino acid transporter 1 (B0AT1), which stabilizes hACE2 homodimers [36]. 


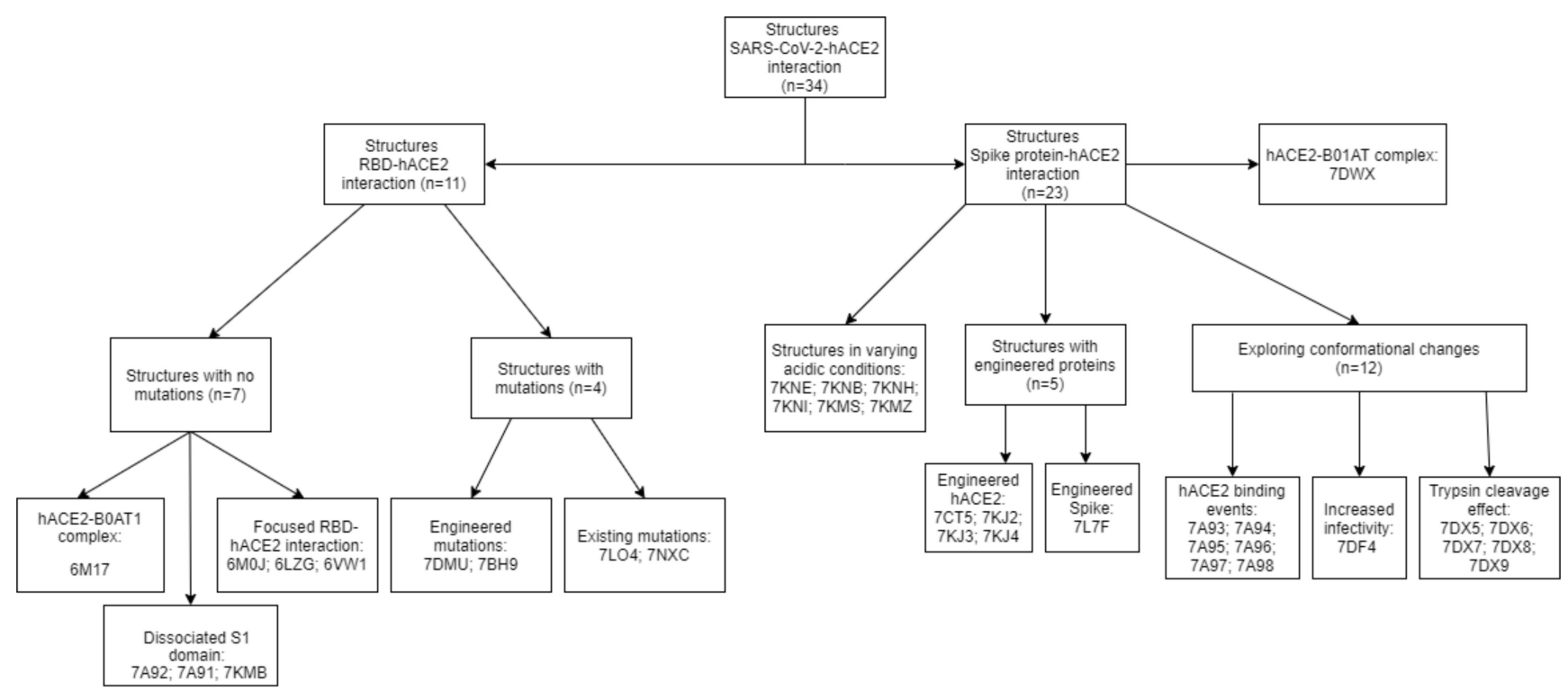

Figure 4. Organizational scheme of all structures found in this review. Molecular graphics analyses were performed with UCSF Chimera and Visual molecular dynamics $[29,33]$. A homology model for the S protein of SARS-CoV-2 Delta variant was created using SWISS-MODEL [37].

\section{Discussion}

\subsection{SARS-CoV-2 Spike RBD - hACE2 Interaction}

\subsubsection{Structures with No Mutation}

The RBD/hACE2 interaction structures represent the domains of both proteins that contribute to this interaction, providing the basis for computational protein-protein interaction studies, mutation analysis, drug design and computational models of the full spike protein, as it is harder to maintain a similar resolution for significantly larger structures [38-41].

The structures used for these analyses represent the wild-type SARS-CoV-2 S protein/ACE2 interaction without mutations (PDB 6VW1/6M0J/6LZG), with an Root Mean Square Distance (RMSD) of $0.32 \AA$ between them (Figure 5) $[39,42]$.

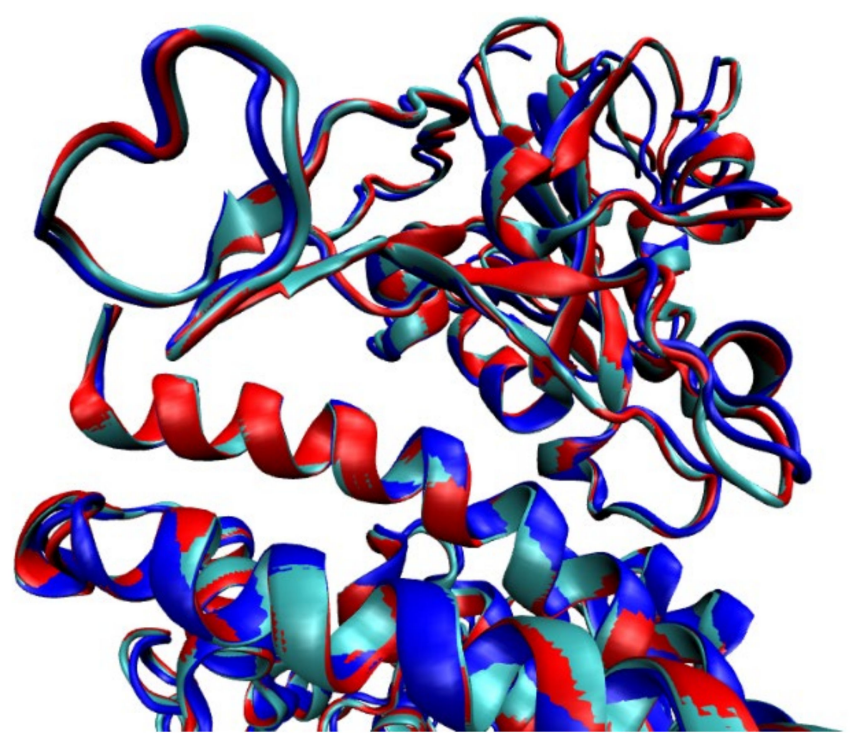

Figure 5. Alignment and superposition of the models representing the interaction with no mutations (PDB 6VW1/6M0J/6LZG) [33]. 
Consistently, in all structures focusing on this interaction in wild-type SARS-CoV-2 $S$ protein, the contact interface is divided into two clusters at both ends of the $\alpha 1$ helix in hACE2, leaving a central cavity filled with water $[40,43]$. In these sections, there are over $10 \mathrm{H}$-bonds, multiple salt bridges, $\pi$-stacking and non-polar interactions $[36,40,43]$.

In the $\mathrm{N}$-terminal portion of the $\alpha 1$ helix, a network of $\mathrm{H}$-bonds is present between Gln493, Gly496, Gln498, Thr500 and Asn501 from the RBD and Lys31, His34, Glu35, Tyr41, Gln42, Leu45, Lys353, and Arg357 from hACE2 (Figure 6B) [43]. Additionally, in the C-terminal portion there are H-bonds (Gln474-Gln24, Asn487-Tyr83), Van der Waals forces (Phe486- Met82) and $\pi$-stacking interactions (Tyr489-Phe28, Phe486-Tyr83), with more interactions through the middle cavity (Lys417/Tyr453 from RBD and Asp30/His34 from hACE2) (Figure 6C) [36,44].

RBD

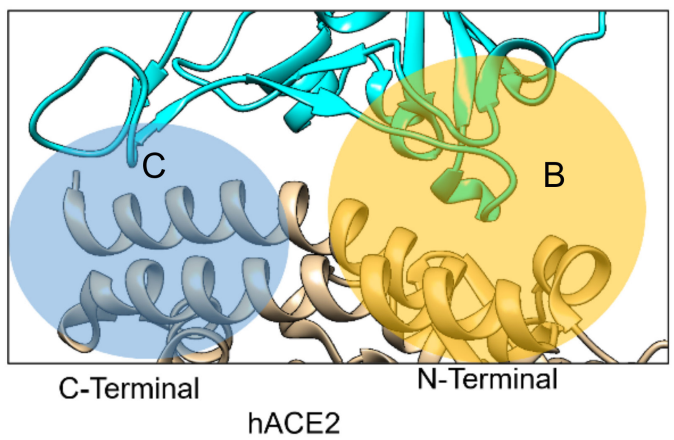

(A)

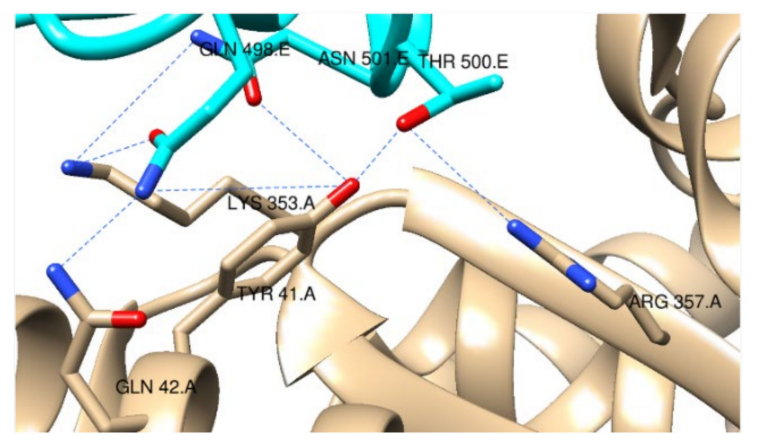

(B)

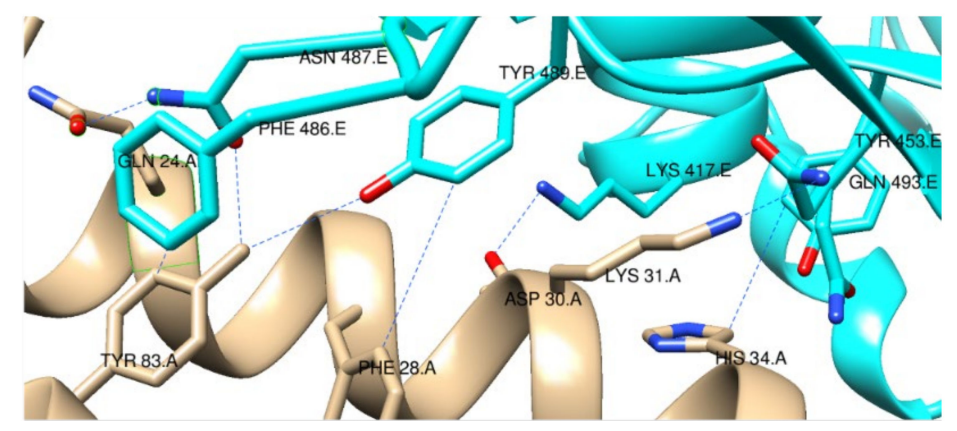

(C)

Figure 6. Interface between SARS-CoV-2 S protein RBD (cyan) and hACE2 (tan), in the S protein/ACE2 interaction without mutations structure (PDB 6M0J). (A) Full view of RBD-hACE2 interface (B) N-terminal portion of the $\alpha 1$ helix with a network of H-bonds (C) C-terminal interactions, with $\pi$-stacking interactions, h-bonds and Van der Waals forces [29].

Some structures also focus the RBD without mutations (PDB 7KMB/7A91/7A92), nevertheless they are reported in studies describing the behaviour of the entire spike protein, where the interaction region was built from non-mutated RBD focused structures (PDB 6VW1/6M0J/6LZG) [39,45].

Determining the structure of full-length human ACE2 bound to the RBD (PDB 6M17) requires the use of an amino acid transporter (B0AT1) to stabilize the protein. When bound to B0AT1, each hACE2 can bind an RBD, suggesting that native dimeric hACE2 can accommodate two S protein trimers [36] Moreover, B0AT1 is not involved in dimerization, thus hACE2 may be a homodimer even in the absence of B0AT1 [36]. Critically, the distance between the ACE2 molecules, particularly for residue D615, is only $53 \AA$, and thus it appears unlikely that the dimeric ACE2 can engage more than one RBD from the same spike protein without substantial conformational changes, although it could bind two RBDs from separate viral particles [46]. 


\subsubsection{Structures with Mutations}

The main goal of determining the structure of a focused RBD without mutations is to understand the behaviour of the wild-type strain and to describe the main interactions of the $S$ protein with hACE2 [43]. When introducing mutations or studying different strains, the goal may be to obtain new therapeutic agents based on either hACE2 or S protein, and to understand why new strains behave differently [23,24,41,47].

The four structures that focus the RBD and have mutations can be further categorized according to the aim of finding new anti-SARS-CoV-2 therapeutic agents (PDB 7DMU/7BH9), or to study mutations in new strains (PDB 7NXC/7LO4).

An hACE2 with mutations to increase the affinity to the viral protein was developed as an anti-SARS-CoV-2 therapeutic agent (PDB 7DMU), achieving more than 100-fold increase in blocking activity, when compared to the wild-type hACE2 [41].

The interaction pattern of engineered hACE2 with the RBD is similar to wild-type hACE2, extending a hydrophobic pocket and adding a new H-bond (K35 - Q493, from hACE2 and RBD, respectively), shortening the distance between hACE2 $\alpha 1$-helix to the RBD by $\sim 1 \AA$ [41]. The use of recombinant hACE2 instead of Abs has an important advantage, given that the resulting mutants with escape mutations have decreased binding affinity to both the engineered and wild-type hACE2, leading to a decrease in virulence [41].

On the other hand, developing a competitive inhibitor from the RBD also holds potential for significant inhibition, particularly as the affinity of the inhibitor with the hACE2 is increased. The RBD inhibitor with the highest binding affinity found (PDB 7BH9) has a RSMD of $0.66 \AA$ when superimposed with the wild type [38]. It was developed from multiple libraries of SARS-CoV-2 clones generated by random mutagenesis and selection of best expressing clones, with several cycles of mutation and testing, attempting to mimic natural evolution in vitro [38].

The mutated RBD (PDB 7BH9) presents, among others, eight amino acid changes actively engaged in the interaction with hACE2, namely V445K, N460K, I468T, T470M, S477N, E484K, Q498R and N501Y. These changes result in additional H-bonds, salt bridges and increased networks of interactions, both stabilizing the structure and resulting in a more positive surface, complementary to the negatively charged hACE2 interaction interface (Figure 7) [38]. The engineered protein can block viral entry and replication, due to an optimized binding, while maintaining no negative effect in the hACE2 enzymatic physiologic activity [38].

Although the optimized structure shows a possible path to design inhibitors, it is noteworthy which mutations are appearing and the sequence in which they appear. Some of the mutations present in the optimized RBD are also present in new variants as critical mutations in variants of concern, appearing often and early in the mutagenesis process, particularly mutations N501Y (variants Alpha, Beta and Gamma) and E484K (variants Beta and Gamma) [48-50]. This may suggest that the in vitro process is possibly mimicking natural evolution, and that artificial selection may have important predictive capabilities over new emerging mutations [41,48,49].Considering the main variants in circulation, only one mutation providing a clear survival advantage is located outside the RBD (mutation D614G, discussed in more detail ahead) [38,51]. The most common mutations appearing in the later phases, suggest that the next variants with increased infectivity might include mutation Q498R or N460K, as they both significantly increase the affinity and emerged late in the optimization process [38].

Besides predicting potential mutations, the optimized structure may also predict the effect on immune evasion. Analysis of 96 Abs revealed that 28 of them bind outside of the hACE2-binding domain, and the interaction was impaired in 9 Abs with major clashes. Additionally, mutation Q498R, besides increasing the affinity with hACE2, was frequently involved in clashes with Abs [38].

Regarding natural occurring mutations, two structures are available, a strain with mutation G485R and variant Gamma. 


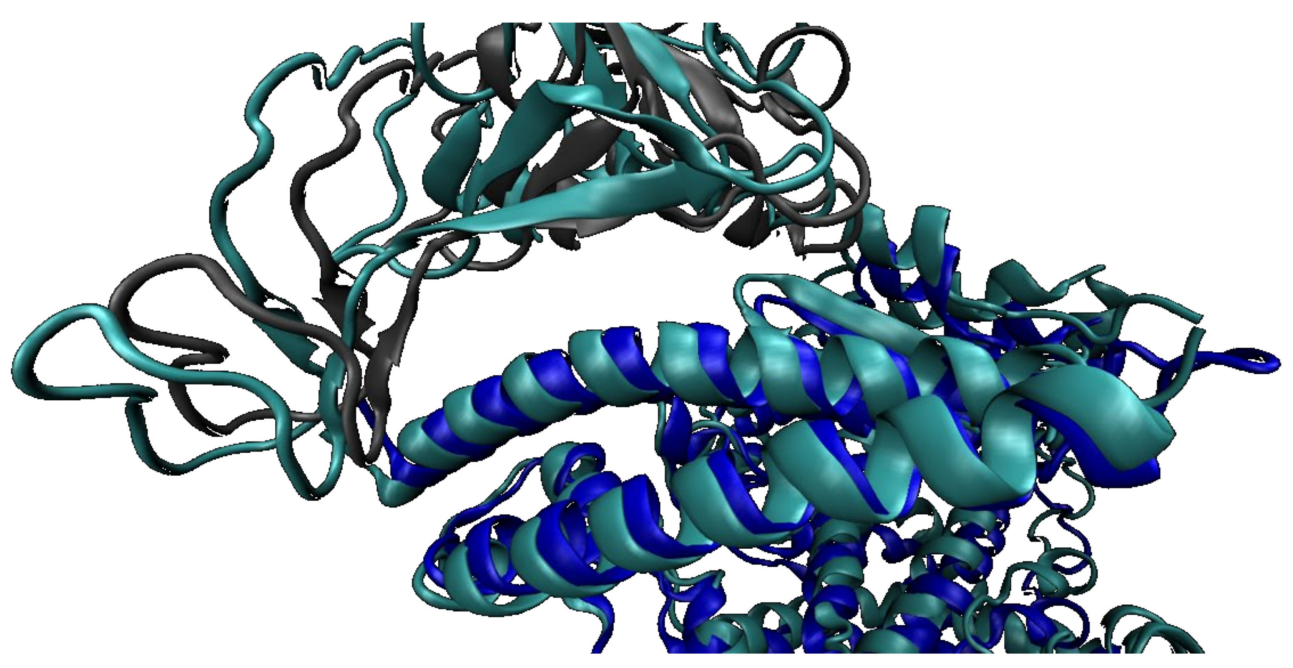

Figure 7. Superimposition and alignment of wild-type RBD and hACE2 (PDB 6LZG) (light blue) and mutated RBD (PDB 7BH9) (hACE2—-dark blue ribbon/SARS-CoV-2 S protein-grey ribbon). The closer distance between the chains from the initial to the optimized model reflects the additional interactions established [33].

In the structure with mutation G485R (PDB 7LO4), residue 485, mutating from glycine to arginine, is not directly involved in the hACE2-SARS-CoV-2 $\mathrm{S}$ protein interaction, but close to $\mathrm{Ab}$ binding epitopes and in a loop region that makes multiple contacts with hACE2. This mutation leads to a rotation in the loop, affecting some interacting residues without significantly reducing the affinity [47]. Nevertheless, the conformational changes in the loop correlate with previous evidence that this mutation plays a role in antigenic escape from neutralising Abs, disrupting interactions involving E484 and F486 (Figure 8) [47].

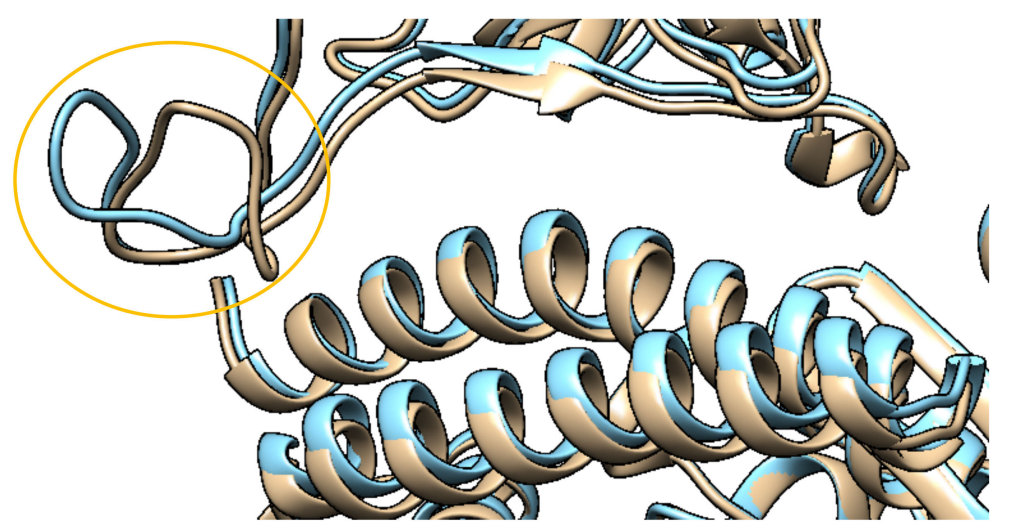

Figure 8. Structural superimposition between the wild-type RBD (Tan) (PDB 6M0J) and with the G485R RBD mutation (Cyan) (PDB 7LO4), with conformational change in the highlighted loop. The RMSD between structures is $0.42 \AA$ [29].

Variant Gamma (PDB 7NXC), has been a cause for concern since it emerged in Brazil in the final months of 2020, showing increased transmissibility and low cross immunity $[23,50]$. One of the defining characteristics of this variant is the high number of mutations, particularly in the spike protein, with three mutations specific to the RBD (K417T, E484K and N501Y), that lead to a 19-fold increase in affinity compared to the Wuhan strain [50]. Mutation K417T deletes a salt bridge with D30 from hACE2, potentially leading to a decreased affinity. Critically, it hinders Ab binding, contributing to the immune escape observed with this strain [24,52]. The increased affinity is due to both mutation E484K, improving the electrostatic complementarity with the negatively charged hACE2, through the change from a carboxylic acid (E) to an amine group (K), and mutation N501Y creating 
an additional ring stacking interaction, with the change from the short-chained asparagine to the aromatic chained tyrosine (Figure 9) [24].

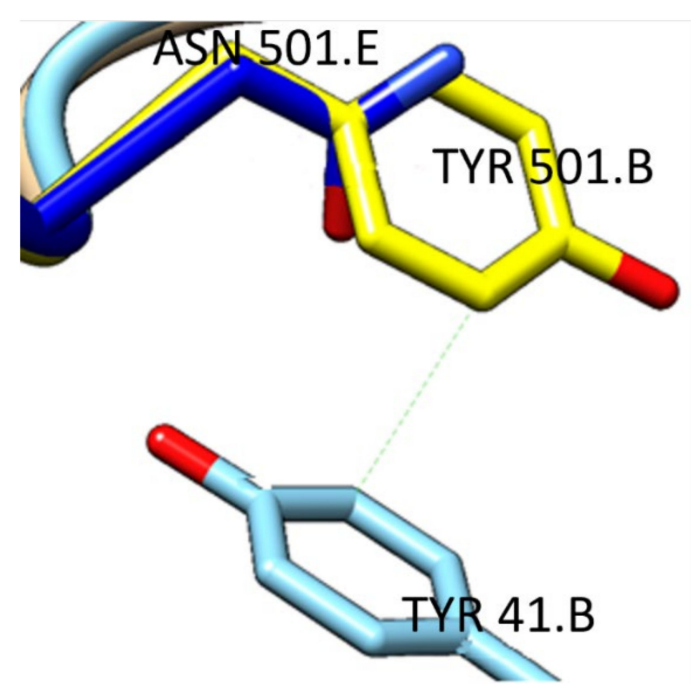

Figure 9. Asparagine-501 from wild-type RBD (PDB 6M0J, carbon atoms in blue) and tyrosine-501 from Gamma variant (PDB 7NXC, carbon atoms in yellow), capable of establishing an additional pi-stacking interaction with tyrosine-41 from hACE2 (bottom) [29].

\subsubsection{RBD Only Structures-Final Remarks}

The interaction interface and critical contacts between hACE2 and SARS-CoV-2 S protein are well understood. Besides having quality structures available, mutations to the RBD critical amino acids result in predictable and replicable changes in binding affinity $[38,40]$. When considering the differences between the wild-type RBD (PDB 6VW1/6M0J/6LZG) and the optimized RBD (PDB 7BH9), there is a path for increased binding, infectivity, and potential new variants. Some changes in the optimized RBD required two nucleotide mutations, which takes longer in natural selection [38]. Importantly, N501Y and E484K were present, emerged frequently in earlier stages and have already been found in emerging variants, suggesting some predicting potential for possible new variants $[24,38]$. The selection of new strains may also be related to the use of low-quality masks, as strains with a higher viral load or a tighter binding spike protein have an advantage over wild-type SARS-CoV-2 [36,38,39,44].

\subsection{SARS-CoV-2 Full Spike Protein-hACE2 Interaction}

\subsubsection{Mutations in the Spike Protein}

In various structures of the full spike protein, some mutations appear often, namely mutation of amino acids 986 and 987 to proline and mutations in the S1/S2 cleavage site. The introduction of two consecutive proline residues, at the beginning of the central helix (residues 986 and 987), is a general strategy to retain $\beta$-coronavirus $S$ proteins in the prototypical prefusion conformation, which facilitates the study of this conformational state [53]. The same occurs with the cleavage site (RRAR) mutation, as mutating this sequence stabilizes the prefusion structure, since cleavage activates the protein $[1,28]$. This cleavage site, recognized by host proteases, is fundamental for the virus, allowing the conformational changes leading to the post-fusion structure [54]. In vivo, it increases infectivity, as proteases is ubiquitously present, and importantly, this effect is present not only in SARS-CoV-2 but also in Influenza viruses and human immunodeficiency viruses [55]. Furthermore, this is a distinct characteristic of SARS-CoV-2 and absent in other $\beta$-coronaviruses, particularly SARS-CoV [55]. 


\subsubsection{SARS-CoV-2 Full Spike Protein-hACE2}

The RBD-hACE2 focused structures highlight the main interactions leading to receptor recognition by SARS-CoV-2, and they are critical for spike protein function. Nevertheless, the spike protein has additional functions in budding and cell fusion, mainly through conformational changes caused by the interactions with hACE2 $[1,28,56]$. Structure determination for the full spike protein will necessarily have limitations due to its size, and usually other structures are used to build the RBD portion of the structure [39]. However, they give an important insight into the major conformational changes to the entire protein and into critical steps culminating in cell fusion and infection $[39,56]$.

The process through which membrane fusion occurs, particularly the entry cell process, is still undefined. This seems to include the interaction between hACE2 and the spike protein, and after recognition, entry occurs via the endosomal pathway or direct cell surface interaction [45]. In both pathways, protein activation requires a protein, either cathepsin L or TMPRSS2 respectively, as full inhibition of both blocks viral entry [45]. When considering the endosomal pathway, it is important to notice the change in $\mathrm{pH}$ and the resulting effects in protein structure, particularly in amino acids containing multiple ionizable groups [45].

The main difference between the structures found at physiological pH (PDB 7KNE/ 7KNB/7KMS) and at $\mathrm{pH} 5.5$ (PDB7KNI/7KNH/7KNE) is the distribution of up and down RBDs. At acidic $\mathrm{pH}$, no double or triple up conformations are observed, with small changes observed at $\mathrm{pH} 4.5$ and $\mathrm{pH}$ 4.0. Starting at $\mathrm{pH} 5.5$, a region in subunit $\mathrm{S} 2$ near the fusion peptide, rich in aspartic acid residues, undergoes a $\mathrm{pH}$-dependent switch, twisting the orientation of disulphide bonds in the structure and causing RBD movement. The domain switch, caused by the $\mathrm{pH}$ in endosomal entry, represents an all-RBD-down locking strategy of immune evasion, that SARS-CoV-2, as other CoVs, potentially uses to avoid neutralization by RBD-up-recognizing Abs [45].

\subsubsection{Before and after hACE2 Binding}

The $\mathrm{S}$ protein gradually undergoes conformational changes as hACE2 binds to the each RBD. Particularly in the first hACE2 binding event, a major conformational change is observed, with a rigid body rotation and center of mass of the S protein movement, exposing the remaining unbound RBDs, further stabilized due to the high affinity with hACE2 [45]. The steps leading from a closed and unbound S protein to a full hACE2 binding decrease the contact area between each $\mathrm{S} 1$ and the corresponding $\mathrm{S} 2$, resulting in a weaker interaction, with the conformational changes driven by hACE2 binding events [39]. These rearrangements and restructuring events in subunits S1 and S2 may have important implications in fusion activation, as the fusion peptide is preceding the S1/S2 contact area [39]. Critically, the cleavage event increases the percentage of RBDs in the up conformation from the closed trimer (PBD 7DX5) to the open timer (PBD 7DX9), increasing the ability to bind the first hACE2 [56].

Briefly, upon cleavage between S1 and S2 domains, an increase in spike trimers in open conformation is observed (unbound open trimer-PBD 7A93), followed by hACE2 binding (1 RBD bound, 2 RBD down-PBD 7A94) and a major conformational change, exposing further RBDs (1 RBD bound, 2 RBDs up - PBD 7A95/7A96) and hACE2 binding (3 RBD bound-PBD 7A97/7A98). The major conformational change and further binding weakens the $\mathrm{S} 1-\mathrm{S} 2$ interaction preceding the fusion peptide region, priming the $\mathrm{S}$ trimer for helical rearrangements in S2, required for viral-host cell membrane fusion [39].

The SARS-CoV-2 original viral S protein population consists mainly of RBD down structures, with S1/S2 uncleaved. The resulting tightly closed conformation of the spike protein is indicative of a conformation masking mechanism for immune evasion of SARS$\mathrm{CoV}-2$, similar to the changes found with low $\mathrm{pH}$, potentially neutralizing RBD-binding Abs [39]. This feature is also described for other CoVs, such as SARS-CoV and MERS$\mathrm{CoV}$ [42]. The ratio of spike proteins with up or down conformation before and after the first hACE2 binding event has a larger increase in SARS-CoV-2, indicating that the conformational masking may be more efficient [42]. 
Another important feature of CoVs, particularly regarding immune evasion, is glycosylation. The large number of N-linked glycans covering the surface of the spike protein of SARS-CoV-2, SARS-CoV and MERS-CoV could pose a challenge to antigen recognition, which thus may help the virus evade immune response [42]. However, in the residues close to the S1/S2 cleavage site, the SARS-CoV-2 trimer forms a glycan hole, a region with less glycosylation than the rest of the protein, resulting in an unhindered access by cleavage enzymes [42].

Taking in account all the events occurring from recognition to cell fusion, SARS-CoV-2 is overall very sensitive to the presence of hACE2, with the open state trimer existing only momentarily in the absence of hACE2 and frequently in its presence. This interaction shifts the protein population characteristics, favouring receptor binding, protein activation and the post-fusion state [42].

\subsubsection{Spike Protein Mutation D614}

From all the mutations in prevalent variants by June 2021 worldwide, mutation D614G is the only one located outside the RBD, and therefore with no direct effect in affinity (PDB 7DF4), but nevertheless, causing increased infectivity and transmission [42,57]. In the closed conformation, portions near the fusion peptide, such as the subdomain 2 and heptad repeat 1 , form multiple hydrogen bonds and salt bridges. From the six bonds established in this zone, four have a direct contribution from the side chain of residue D614, suggesting that this amino acid may be essential for this interaction and subsequent stabilization of the prefusion conformation [42,57].

In general, mutation D614G greatly disturbs the interactions between subunits $\mathrm{S} 1$ and S2, due to the weakened interactions established by the side chain of glycine, in comparison with aspartic acid [42,57]. As a result, the energy barrier for the conformational change is reduced and SARS-CoV-2 D614G strains have increased sensitivity to the presence of hACE2, which could be the underlying mechanism for enhanced infectivity observed in these strains [42]. On the other hand, given the increase of RBDs in the up position, these strains are more susceptible to neutralization by RBD-directed Abs [58].

\subsubsection{Full Spike Protein Neutralization Strategies}

Soluble hACE2 has demonstrated a protective role against SARS-CoV2 infection, blocking viral entry in cell cultures and human organoids. Due to this activity, recombinant soluble hACE2 is already enrolled in several clinical trials, as a promising treatment for SARS-CoV-2 infection [59]. The use of ACE2 as a neutralizing agent can be achieved in several ways, either by increasing the affinity or engineering dimers and trimers capable of binding several RBDs. The spike protein can bind three hACE2 molecules and, as such, it is expected that a trimeric ACE2 with a linker can inhibit SARS-CoV-2. S proteins bound to one or more hACE2 have guided the design of ACE2-based viral inhibitors (PDB $7 \mathrm{KJ} 2 / 7 \mathrm{KJ} 3 / 7 \mathrm{KJ} 4$ ) [59]. The binding strength of constructs using a monomer, a dimer, and a trimer of hACE2, with engineered linkers, increases as expected. The trimer structure was then optimized, resulting in a trimeric ACE2 with a 200-fold increase in binding affinity, when compared with soluble wild-type hACE2, all without hindering the physiological functions of ACE2 in the angiotensin-renin system [59]. Notably, the neutralization potency of ACE2 constructs gradually increases with the size of the construct, and correlates strictly with the binding affinity, suggesting that the interaction between the RBD and hACE2 is the main component of neutralization [59]. Further improvements of these ACE2-based therapeutic candidates include modifications to enhance protein stability, to modulate peptidase activity and to increase its in vivo residence time in circulation [59].

An engineered ACE2-rigid-foldon, as a trimeric protein (PDB 7CT5) inhibits eight naturally occurring mutants, including D614G and seven other RBD domain mutants [46]. The inhibition of SARS-CoV-2 by the trimeric hACE2 occurs due to the simultaneous binding of all three RBD in each spike trimer, which stabilizes the viral protein in a three- 
RBD-up conformation and, as this was the only conformation found, it shows the striking ability of these trimers to change the conformation of the spike protein population [46].

\subsubsection{Spike Vaccine Candidate}

Considering $\mathrm{Ab}$ potency for virus neutralizing effects, competition with hACE2 for RBD binding is a key predictor [30]. Hence, the spike protein is the prime candidate for vaccine development, in order to elicit the appearance of Abs directed at the spike protein. The S protein resulting from the coding sequence (mRNA) in the vaccine candidate BNT162b2 (PDB 7L7F), consists of a trimeric S protein capable of binding hACE2 with high affinity and structurally intact receptor binding sites. This is achieved due to a stabilization of the protein in the prefusion conformation, by substitution of residues 986 and 987 [60]. The altered spike protein induces a high functional $\mathrm{Ab}$ response both in mice and non-human primates (macaques), protecting them from infection with SARS-CoV-2, demonstrated by an absence of detectable RNA by RT-qPCR in the lower pulmonary tract [60].

\subsection{Delta Variant}

Spike protein mutations can be selected for either increased infectivity, generally from an increased interaction with hACE2, or decreased immune response, affecting Ab binding. As such, mutations in the spike protein are a fundamental aspect in variants of concern. Notably, one mutation is common to all prevalent strains worldwide, D614G, associated with increased infectivity, although with no direct effect to the RBD [42].

Variant Delta appeared in India in late 2020 and is becoming the dominant strain worldwide, responsible for most infections in the US, Europe, South Africa and Australia [61,62]. Importantly, this variant combines mutations affecting infectivity and potential immune escape (Table 2) [16]. Early data have shown that viral loads are 1,000 times higher with this strain, when compared with the Wuhan strain, which also contributes to increased transmission [63].

Table 2. List of mutations found in the spike protein of the Delta variant.

\begin{tabular}{|c|c|c|c|c|c|}
\hline Mutation & Location & Effect on Affinity & Effect on Immune Response & Additional Information & References \\
\hline T19R & S1/NTD & No effect reported & $\begin{array}{l}\text { Affects NTD- } \\
\text { directed Abs }\end{array}$ & \multirow{4}{*}{$\begin{array}{l}\text { Change in NTD } \\
\text { antigenic site }\end{array}$} & \multirow{4}{*}[32,64]{} \\
\hline E156- & S1/NTD & No effect reported & $\begin{array}{l}\text { Affects NTD- } \\
\text { directed Abs }\end{array}$ & & \\
\hline F157- & S1/NTD & No effect reported & $\begin{array}{l}\text { Affects NTD- } \\
\text { directed Abs }\end{array}$ & & \\
\hline R158G & S1/NTD & No effect reported & Affects NTD-directed Abs & & \\
\hline $\mathrm{K} 417 \mathrm{~N}$ & RBD & $\begin{array}{l}\text { Potential decrease in } \\
\text { affinity }\end{array}$ & $\begin{array}{l}\text { Moderately decreases } \\
\text { RBD-directed Abs }\end{array}$ & $\begin{array}{l}\text { Affects only less important class } \\
\text { of Abs }\end{array}$ & {$[24,52]$} \\
\hline L452R & RBD & No effect reported & $\begin{array}{l}\text { Severely affects } \\
\text { RBD-directed Abs }\end{array}$ & None & {$[52,64]$} \\
\hline $\mathrm{T} 478 \mathrm{~K}$ & RBD & $\begin{array}{l}\text { Increases electrostatic } \\
\text { complementarity }\end{array}$ & $\begin{array}{l}\text { Moderately decreases } \\
\text { RBD-directed Abs }\end{array}$ & Three additional H-bonds formed & {$[65-67]$} \\
\hline D614G & S1-S2 & No effect reported & $\begin{array}{c}\text { Increases susceptibility to } \\
\text { neutralization by } \\
\text { RBD-directed Abs }\end{array}$ & $\begin{array}{l}\text { Changes protein dynamics } \\
\text { Increased viral loads and } \\
\text { transmission }\end{array}$ & {$[52,58]$} \\
\hline P681R & $\mathrm{S} 2$ & No effect reported & No effect reported & $\begin{array}{c}\text { Increased } S 1 / S 2 \text { cleavage and } \\
\text { viral fusion }\end{array}$ & {$[66]$} \\
\hline D950N & $\mathrm{S} 2$ & No effect reported & No effect reported & Change protein dynamics & [67] \\
\hline
\end{tabular}


Regarding infectivity, this strain possesses mutation D614G and one mutation in the RBD, T478K. Despite no effect with direct bonds or contacts, it increases the electrostatic complementary between the proteins [65]. As such, it is hypothesised that the Delta variant emerged mainly as a result of reduced immune recognition and enhanced transmissibility nonrelated with affinity (effects from mutations D614G, P681 and D950N) [68]. Importantly, mutation N501Y is not found in the Delta variant, in contrast with all other variants of concern.Mutation N501Y results in the highest increase in hACE2 affinity conferred by a single RBD mutation [52].

Potentially fundamental for immune escape are mutations $\mathrm{K} 417 \mathrm{~N}$, and particularly L452R, both affecting Ab binding, and occurring in the RBD [64]. L452R has also appeared in variant Epsilon identified in California, reaching a maximum of $20 \%$ of new cases in the United States, before variant Delta became prevalent $[61,69]$. Although no structure on the Delta variant RBD is available, a homology model of the Delta variant RBD was built, using SWISS-MODEL, and the effect of specific and new mutations can be predicted [37]. Homology modelling is a method that predicts a 3D structure based on the aminoacidic sequence, with the only requirement of an existing experimental structure with at least $30 \%$ sequence identity [70]. The genome selected to represent the Delta strain was MZ377116, retrieved from the SARS-CoV-2 Data Hub (NCBI Virus) [71].

Mutation L452R causes a steric hindrance to $\mathrm{Ab}$ binding, retrieved from structure 7CM4, without affecting binding to hACE2 (Figure 10) but causing a greater than 10-fold decrease in neutralization potency for RBD-specific Abs [61,69]. Crucially, variant Epsilon has additional mutations, S13I and W152C, resulting in severe decrease of neutralization for NTD-directed Abs, due to a new disulphide bond inducing a conformational change [64]. In the Delta variant, mutations T19R, E156-, F157- and R158G severely affect NTD directed Abs, due to the adoption of an alpha-helical conformation, instead of the original $\beta$ strand $[64,68]$.

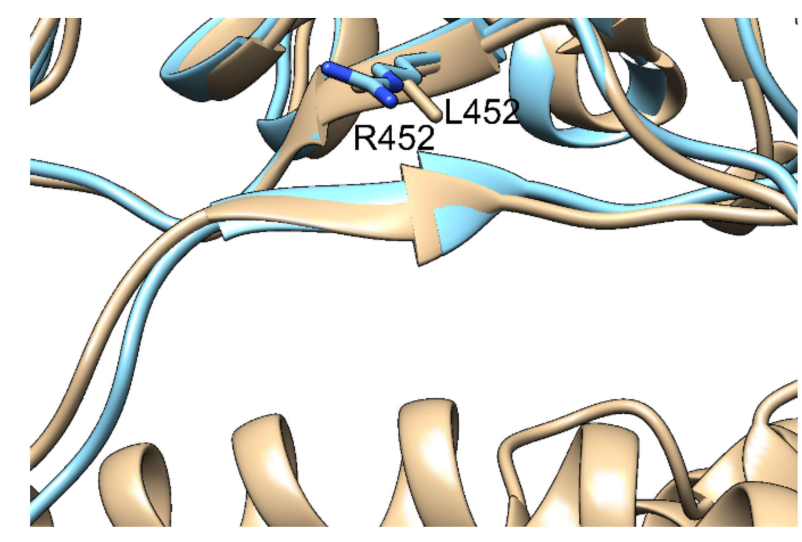

(A)

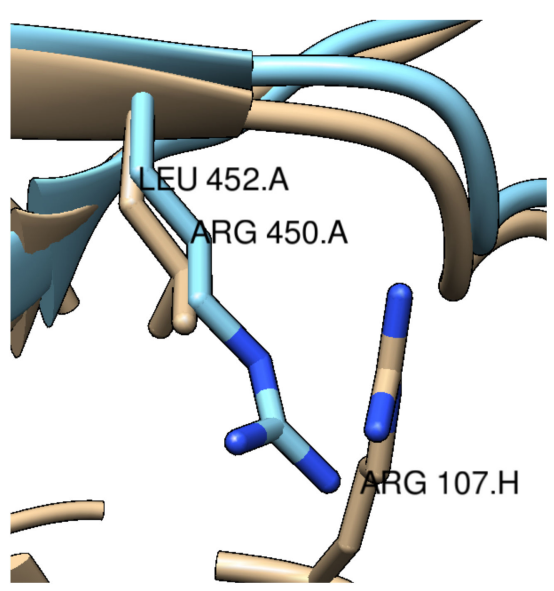

(B)

Figure 10. Mutation L452R, with the original variant from wild-type RBD (PDB 6M0J) (cyan) and the homology model of Delta variant (tan), obtained from genome MZ377116.1 (A) Superimposition of RBDs from original variant and Delta variant. Steric hindrance observed with Arg107 from Ab from structure 7CM4, due to a longer side chain in Delta variant (B) RBDs of original and delta variant structures with no steric hindrance regarding hACE2 [29].

Variant Epsilon has been deescalated from variant of concern due the decrease in community transmission, being replaced by the Delta variant $[14,16]$.

\section{Conclusions}

The structures available in the Protein Data Bank provide important insights into SARS-CoV-2 spike protein behaviour, clarifying the conformational changes across the protein leading to post-fusion conformation and cell infection. In general, the spike protein is highly sensitive to the presence and binding of hACE2 to the RBDs, with an allosteric 
effect, destabilizing the S1/S2 interaction and facilitating the final conformational change. The affinity of the complex formed in cell recognition is critical for infectivity, with consequences in the epidemiology of SARS-CoV-2. As such, the RBD is also an important target for neutralizing Abs.

The appearance of new variants has increased SARS-CoV-2 fitness, mainly by increasing infectivity, or decreasing immune response. The Delta variant carries particular mutations associated with increased viral fitness through decreased antibody binding, increased RBD affinity and altered protein dynamics, which justifies the increased prevalence worldwide [67,72]. Despite this, some of the most common mutations increasing affinity in other variants are absent, which still show potential for evolution [52,61].

The ability to predict infectivity and immune escape for new variants is crucial to decrease their impact. As such, mutagenesis studies have also shown an important predicting capacity for the major mutations in current variants of concern [38]. Combining both existing mutations and mutagenesis studies, new potential SARS-CoV-2 variants, harboring advantageous $\mathrm{S}$ protein mutations, may be predicted. These include mutations S13I and W152C, decreasing antibody binding, N460K, increasing RDB affinity, or Q498R, positively affecting both properties

Author Contributions: L.Q.-R.: conceptualization, data curation and investigation, formal analysis, methodology, and writing original draft preparation; P.G.d.S. and J.G.: conceptualization, review of the writing and substance of this article, supervision and validation M.B., A.B. and J.R.M.: conceptualization, data curation and investigation, supervision, and validation. All authors have read and agreed to the published version of the manuscript.

Funding: This research received no external funding.

Acknowledgments: L.Q.-R. would like to acknowledge Fundação para a Ciência e para a Tecnologia for the grant "2020.10230.BD" under the program "DOCTORATES 4 COVID-19".

Conflicts of Interest: The authors declare no conflict of interest.

\section{References}

1. Wang, M.Y.; Zhao, R.; Gao, L.J.; Gao, X.F.; Wang, D.P.; Cao, J.M. SARS-CoV-2: Structure, Biology, and Structure-Based Therapeutics Development. Front Cell Infect. Microbiol. 2020, 10, 587269. [CrossRef] [PubMed]

2. WHO Director-General's Opening Remarks at the Media Briefing on COVID-19-11 March 2020. Available online: https: //www.who.int/director-general/speeches/detail/who-director-general-s-opening-remarks-at-the-media-briefing-oncovid-19---11-march-2020 (accessed on 3 September 2021).

3. WHO. Coronavirus Disease (COVID-19) Dashboard. Available online: https:/ / covid19.who.int/ (accessed on 4 September 2021).

4. Zhao, J.; Cui, W.; Tian, B.-p. The Potential Intermediate Hosts for SARS-CoV-2. Front. Microbiol. 2020, 11, 2400. [CrossRef] [PubMed]

5. Woo, P.C.; Lau, S.K.; Huang, Y.; Yuen, K.Y. Coronavirus diversity, phylogeny and interspecies jumping. Exp. Biol. Med. (Maywood) 2009, 234, 1117-1127. [CrossRef] [PubMed]

6. Schoeman, D.; Gordon, B.; Fielding, B.C. Pathogenic Human Coronaviruses. Ref. Modul. Biomed. Sci. 2021, B978-970-912-818731818739.800052-818735. [CrossRef]

7. Huang, Y.; Yang, C.; Xu, X.-f.; Xu, W.; Liu, S.-w. Structural and functional properties of SARS-CoV-2 spike protein: Potential antivirus drug development for COVID-19. Acta Pharmacol. Sin. 2020, 41, 1141-1149. [CrossRef]

8. Cubuk, J.; Alston, J.J.; Incicco, J.J.; Singh, S.; Stuchell-Brereton, M.D.; Ward, M.D.; Zimmerman, M.I.; Vithani, N.; Griffith, D.; Wagoner, J.A.; et al. The SARS-CoV-2 nucleocapsid protein is dynamic, disordered, and phase separates with RNA. Nat. Commun. 2021, 12, 1936. [CrossRef]

9. Fan, Y.; Zhao, K.; Shi, Z.-L.; Zhou, P. Bat Coronaviruses in China. Viruses 2019, 11, 210. [CrossRef] [PubMed]

10. WHO. Coronavirus disease (COVID-19): How is it transmitted? Available online: https://www.who.int/news-room/q-a-detail/ coronavirus-disease-covid-19-how-is-it-transmitted (accessed on 18 August 2021).

11. Hu, B.; Guo, H.; Zhou, P.; Shi, Z.L. Characteristics of SARS-CoV-2 and COVID-19. Nat. Rev. Microbiol. 2021, 19, 141-154. [CrossRef]

12. Wu, F.; Zhao, S.; Yu, B.; Chen, Y.-M.; Wang, W.; Song, Z.-G.; Hu, Y.; Tao, Z.-W.; Tian, J.-H.; Pei, Y.-Y.; et al. A new coronavirus associated with human respiratory disease in China. Nature 2020, 579, 265-269. [CrossRef]

13. Janik, E.; Niemcewicz, M.; Podogrocki, M.; Majsterek, I.; Bijak, M. The Emerging Concern and Interest SARS-CoV-2 Variants. Pathogens 2021, 10, 633. [CrossRef] 
14. ECDC. SARS-CoV-2 Variants of Concern as of 9 September 2021. Available online: https://www.ecdc.europa.eu/en/covid-19 /variants-concern (accessed on 15 September 2021).

15. WHO. Tracking SARS-CoV-2 Variants. Available online: https://www.who.int/en/activities/tracking-SARS-CoV-2-variants/ (accessed on 14 September 2021).

16. CDC. SARS-CoV-2 Variant Classifications and Definitions. Available online: https://www.cdc.gov/coronavirus/2019-ncov/ variants/variant-info.html\#Concern (accessed on 14 September 2021).

17. CDC. Centers for Disease Control and Prevention. Available online: https://www.cdc.gov/ (accessed on 29 July 2021$)$.

18. ECDC. European Centre for Disease Prevention and Control. Available online: https://www.ecdc.europa.eu/en (accessed on 29 July 2021).

19. Madhi, S.A.; Baillie, V.; Cutland, C.L.; Voysey, M.; Koen, A.L.; Fairlie, L.; Padayachee, S.D.; Dheda, K.; Barnabas, S.L.; Bhorat, Q.E.; et al. Efficacy of the ChAdOx1 nCoV-19 Covid-19 Vaccine against the B.1.351 Variant. New Engl. J. Med. 2021, 384, 1885-1898. [CrossRef]

20. Cele, S.; Gazy, I.; Jackson, L.; Hwa, S.-H.; Tegally, H.; Lustig, G.; Giandhari, J.; Pillay, S.; Wilkinson, E.; Naidoo, Y.; et al. Escape of SARS-CoV-2 501Y.V2 from neutralization by convalescent plasma. Nature 2021, 593, 142-146. [CrossRef]

21. Pearson, C.A.; Russell, T.W.; Davies, N.G. Estimates of Severity and Transmissibility of Novel South Africa SARS-CoV-2 Varian 501Y.V2. Available online: https://cmmid.github.io/topics/covid19/reports/sa-novel-variant/2021_01_11_Transmissibility_ and_severity_of_501Y_V2_in_SA.pdf (accessed on 14 September 2021).

22. Funk, T.; Pharris, A.; Spiteri, G.; Bundle, N.; Melidou, A.; Carr, M.; Gonzalez, G.; Garcia-Leon, A.; Crispie, F.; O'Connor, L.; et al. Characteristics of SARS-CoV-2 variants of concern B.1.1.7, B.1.351 or P.1: Data from seven EU/EEA countries, weeks $38 / 2020$ to 10/2021. Eurosurveillance 2021, 26, 2100348. [CrossRef] [PubMed]

23. Faria, N.R.; Mellan, T.A.; Whittaker, C.; Claro, I.M.; Candido, D.d.S.; Mishra, S.; Crispim, M.A.E.; Sales, F.C.S.; Hawryluk, I.; McCrone, J.T.; et al. Genomics and epidemiology of the P.1 SARS-CoV-2 lineage in Manaus, Brazil. Science 2021, 372, 815-821. [CrossRef]

24. Dejnirattisai, W.; Zhou, D.; Supasa, P.; Liu, C.; Mentzer, A.J.; Ginn, H.M.; Zhao, Y.; Duyvesteyn, H.M.E.; Tuekprakhon, A.; Nutalai, R.; et al. Antibody evasion by the P.1 strain of SARS-CoV-2. Cell 2021, 184, 2939-2954.e9. [CrossRef]

25. Eli-Lilly. FACT SHEET FOR HEALTH CARE PROVIDERS EMERGENCY USE AUTHORIZATION (EUA) OF BAMLANIVIMAB AND ETESEVIMAB. Available online: https://www.fda.gov/media/145802/download (accessed on 15 September 2021).

26. Uriu, K.; Kimura, I.; Shirakawa, K.; Takaori-Kondo, A.; Nakada, T.-a.; Kaneda, A.; Consortium, T.G.t.P.J.; Nakagawa, S.; Sato, K. Ineffective neutralization of the SARS-CoV-2 Mu variant by convalescent and vaccine sera. bioRxiv 2021, 2021.2009.2006.459005. [CrossRef]

27. Ni, W.; Yang, X.; Yang, D.; Bao, J.; Li, R.; Xiao, Y.; Hou, C.; Wang, H.; Liu, J.; Yang, D.; et al. Role of angiotensin-converting enzyme 2 (ACE2) in COVID-19. Crit. Care 2020, 24, 422. [CrossRef]

28. Wrapp, D.; Wang, N.; Corbett, K.S.; Goldsmith, J.A.; Hsieh, C.-L.; Abiona, O.; Graham, B.S.; McLellan, J.S. Cryo-EM structure of the 2019-nCoV spike in the prefusion conformation. Science 2020, 367, 1260-1263. [CrossRef] [PubMed]

29. Pettersen, E.F.; Goddard, T.D.; Huang, C.C.; Couch, G.S.; Greenblatt, D.M.; Meng, E.C.; Ferrin, T.E. UCSF Chimera-a visualization system for exploratory research and analysis. J. Comput. Chem. 2004, 25, 1605-1612. [CrossRef] [PubMed]

30. Ju, B.; Zhang, Q.; Ge, J.; Wang, R.; Sun, J.; Ge, X.; Yu, J.; Shan, S.; Zhou, B.; Song, S.; et al. Human neutralizing antibodies elicited by SARS-CoV-2 infection. Nature 2020, 584, 115-119. [CrossRef] [PubMed]

31. Xia, S.; Liu, M.; Wang, C.; Xu, W.; Lan, Q.; Feng, S.; Qi, F.; Bao, L.; Du, L.; Liu, S.; et al. Inhibition of SARS-CoV-2 (previously 2019-nCoV) infection by a highly potent pan-coronavirus fusion inhibitor targeting its spike protein that harbors a high capacity to mediate membrane fusion. Cell Res. 2020, 30, 343-355. [CrossRef] [PubMed]

32. McCallum, M.; Marco, A.; Lempp, F.; Tortorici, M.A.; Pinto, D.; Walls, A.C.; Beltramello, M.; Chen, A.; Liu, Z.; Zatta, F.; et al. $\mathrm{N}$-terminal domain antigenic mapping reveals a site of vulnerability for SARS-CoV-2. bioRxiv 2021. [CrossRef]

33. Humphrey, W.; Dalke, A.; Schulten, K. VMD: Visual molecular dynamics. J. Mol. Graph. 1996, 14, 33-38. [CrossRef]

34. Huo, J.; Zhao, Y.; Ren, J.; Zhou, D.; Duyvesteyn, H.M.E.; Ginn, H.M.; Carrique, L.; Malinauskas, T.; Ruza, R.R.; Shah, P.N.M.; et al. Neutralization of SARS-CoV-2 by Destruction of the Prefusion Spike. Cell Host Microbe 2020, 28, 445-454.e6. [CrossRef] [PubMed]

35. Mahase, E. Delta variant: What is happening with transmission, hospital admissions, and restrictions? BMJ 2021, $373, \mathrm{n} 1513$. [CrossRef]

36. Yan, R.; Zhang, Y.; Li, Y.; Xia, L.; Guo, Y.; Zhou, Q. Structural basis for the recognition of SARS-CoV-2 by full-length human ACE2. Science 2020, 367, 1444-1448. [CrossRef]

37. Waterhouse, A.; Bertoni, M.; Bienert, S.; Studer, G.; Tauriello, G.; Gumienny, R.; Heer, F.T.; de Beer, T.A.P.; Rempfer, C.; Bordoli, L.; et al. SWISS-MODEL: Homology modelling of protein structures and complexes. Nucleic Acids Res. 2018, 46, W296-W303. [CrossRef]

38. Zahradník, J.; Marciano, S.; Shemesh, M.; Zoler, E.; Chiaravalli, J.; Meyer, B.; Dym, O.; Elad, N.; Schreiber, G. SARSCoV-2 RBD in vitroevolution follows contagious mutation spread, yet generates an able infection inhibitor. bioRxiv 2021, 2021.2001.2006.425392. [CrossRef]

39. Benton, D.J.; Wrobel, A.G.; Xu, P.; Roustan, C.; Martin, S.R.; Rosenthal, P.B.; Skehel, J.J.; Gamblin, S.J. Receptor binding and priming of the spike protein of SARS-CoV-2 for membrane fusion. Nature 2020, 588, 327-330. [CrossRef] 
40. Delgado Blanco, J.; Hernandez-Alias, X.; Cianferoni, D.; Serrano, L. In silico mutagenesis of human ACE2 with S protein and translational efficiency explain SARS-CoV-2 infectivity in different species. PLoS Comput. Biol. 2020, 16, e1008450. [CrossRef]

41. Higuchi, Y.; Suzuki, T.; Arimori, T.; Ikemura, N.; Mihara, E.; Kirita, Y.; Ohgitani, E.; Mazda, O.; Motooka, D.; Nakamura, S.; et al. High affinity modified ACE2 receptors protect from SARS-CoV-2 infection in hamsters. biorXiv 2020. [CrossRef]

42. Xu, C.; Wang, Y.; Liu, C.; Zhang, C.; Han, W.; Hong, X.; Wang, Y.; Hong, Q.; Wang, S.; Zhao, Q.; et al. Conformational dynamics of SARS-CoV-2 trimeric spike glycoprotein in complex with receptor ACE2 revealed by cryo-EM. Sci. Adv. 2021, 7. [CrossRef]

43. Lan, J.; Ge, J.; Yu, J.; Shan, S.; Zhou, H.; Fan, S.; Zhang, Q.; Shi, X.; Wang, Q.; Zhang, L.; et al. Structure of the SARS-CoV-2 spike receptor-binding domain bound to the ACE2 receptor. Nature 2020, 581, 215-220. [CrossRef]

44. Shang, J.; Ye, G.; Shi, K.; Wan, Y.; Luo, C.; Aihara, H.; Geng, Q.; Auerbach, A.; Li, F. Structural basis of receptor recognition by SARS-CoV-2. Nature 2020, 581, 221-224. [CrossRef] [PubMed]

45. Zhou, T.; Tsybovsky, Y.; Gorman, J.; Rapp, M.; Cerutti, G.; Chuang, G.-Y.; Katsamba, P.S.; Sampson, J.M.; Schön, A.; Bimela, J.; et al. Cryo-EM Structures of SARS-CoV-2 Spike without and with ACE2 Reveal a pH-Dependent Switch to Mediate Endosomal Positioning of Receptor-Binding Domains. Cell Host Microbe 2020, 28, 867-879.e5. [CrossRef] [PubMed]

46. Guo, L.; Bi, W.; Wang, X.; Xu, W.; Yan, R.; Zhang, Y.; Zhao, K.; Li, Y.; Zhang, M.; Cai, X.; et al. Engineered trimeric ACE2 binds viral spike protein and locks it in "Three-up" conformation to potently inhibit SARS-CoV-2 infection. Cell Res. 2021, 31, 98-100. [CrossRef] [PubMed]

47. Weekley, C.M.; Purcell, D.F.J.; Parker, M.W. SARS-CoV-2 Spike receptor-binding domain with a G485R mutation in complex with human ACE2. bioRxiv 2021, 2021.2003.2016.434488. [CrossRef]

48. Hodcroft, E. Variant: 20I (Alpha, V1). Available online: https:/ / covariants.org/variants/20I.Alpha.V1 (accessed on 7 July 2021).

49. Hodcroft, E. Variant: 20H (Beta, V2). Available online: https:/ / covariants.org/variants/20H.Beta.V2 (accessed on 7 July 2021).

50. Hodcroft, E. Variant: 20J (Gamma, V3). Available online: https://covariants.org/variants/20J.Gamma.V3 (accessed on 7 July 2021).

51. Juraszek, J.; Rutten, L.; Blokland, S.; Bouchier, P.; Voorzaat, R.; Ritschel, T.; Bakkers, M.J.G.; Renault, L.L.R.; Langedijk, J.P.M. Stabilizing the closed SARS-CoV-2 spike trimer. Nat. Commun. 2021, 12, 244. [CrossRef] [PubMed]

52. Harvey, W.T.; Carabelli, A.M.; Jackson, B.; Gupta, R.K.; Thomson, E.C.; Harrison, E.M.; Ludden, C.; Reeve, R.; Rambaut, A.; Peacock, S.J.; et al. SARS-CoV-2 variants, spike mutations and immune escape. Nat. Rev. Microbiol. 2021, 19, 409-424. [CrossRef] [PubMed]

53. Pallesen, J.; Wang, N.; Corbett, K.S.; Wrapp, D.; Kirchdoerfer, R.N.; Turner, H.L.; Cottrell, C.A.; Becker, M.M.; Wang, L.; Shi, W.; et al. Immunogenicity and structures of a rationally designed prefusion MERS-CoV spike antigen. Proc. Natl. Acad. Sci. USA 2017, 114, E7348-E7357. [CrossRef]

54. Xia, X. Domains and Functions of Spike Protein in Sars-Cov-2 in the Context of Vaccine Design. Viruses 2021, 13, 109. [CrossRef] [PubMed]

55. Johnson, B.A.; Xie, X.; Bailey, A.L.; Kalveram, B.; Lokugamage, K.G.; Muruato, A.; Zou, J.; Zhang, X.; Juelich, T.; Smith, J.K.; et al. Loss of furin cleavage site attenuates SARS-CoV-2 pathogenesis. Nature 2021, 591, 293-299. [CrossRef] [PubMed]

56. Yan, R.; Zhang, Y.; Li, Y.; Ye, F.; Guo, Y.; Xia, L.; Zhong, X.; Chi, X.; Zhou, Q. Structural basis for the different states of the spike protein of SARS-CoV-2 in complex with ACE2. Cell Res. 2021, 31, 717-719. [CrossRef] [PubMed]

57. WHO. SARS-CoV-2 Variants. Available online: https://www.who.int/csr/don/31-december-2020-sars-cov2-variants/en/ (accessed on 3 September 2021).

58. Weissman, D.; Alameh, M.G.; de Silva, T.; Collini, P.; Hornsby, H.; Brown, R.; LaBranche, C.C.; Edwards, R.J.; Sutherland, L.; Santra, S.; et al. D614G Spike Mutation Increases SARS CoV-2 Susceptibility to Neutralization. Cell Host Microbe. 2021, 29, 23-31.e24. [CrossRef] [PubMed]

59. Xiao, T.; Lu, J.; Zhang, J.; Johnson, R.I.; McKay, L.G.A.; Storm, N.; Lavine, C.L.; Peng, H.; Cai, Y.; Rits-Volloch, S.; et al. A trimeric human angiotensin-converting enzyme 2 as an anti-SARS-CoV-2 agent in vitro. bioRxiv 2020. [CrossRef]

60. Vogel, A.B.; Kanevsky, I.; Che, Y.; Swanson, K.A.; Muik, A.; Vormehr, M.; Kranz, L.M.; Walzer, K.C.; Hein, S.; Güler, A.; et al. BNT162b vaccines protect rhesus macaques from SARS-CoV-2. Nature 2021, 592, 283-289. [CrossRef]

61. Hodcroft, E. Variant: 21A (Delta). Available online: https:/ / covariants.org/variants/21A.Delta (accessed on 7 July 2021).

62. ECDC. SARS-COV-2 Delta variant now dominant in much of the European Region and efforts must be reinforced to prevent transmission, warn WHO/Europe and ECDC. Available online: https://www.ecdc.europa.eu/en/news-events/sars-cov-2delta-variant-now-dominant-european-region (accessed on 18 August 2021).

63. Li, B.; Deng, A.; Li, K.; Hu, Y.; Li, Z.; Xiong, Q.; Liu, Z.; Guo, Q.; Zou, L.; Zhang, H.; et al. Viral infection and transmission in a large well-traced outbreak caused by the Delta SARS-CoV-2 variant. medRxiv 2021, 2021.2007.2007.21260122. [CrossRef]

64. McCallum, M.; Bassi, J.; De Marco, A.; Chen, A.; Walls, A.C.; Di Iulio, J.; Tortorici, M.A.; Navarro, M.-J.; Silacci-Fregni, C.; Saliba, C.; et al. SARS-CoV-2 immune evasion by the B.1.427/B.1.429 variant of concern. Science 2021, eabi7994. [CrossRef]

65. Di Giacomo, S.; Mercatelli, D.; Rakhimov, A.; Giorgi, F.M. Preliminary report on severe acute respiratory syndrome coronavirus 2 (SARS-CoV-2) Spike mutation T478K. J. Med. Virol. 2021, 93, 5638-5643. [CrossRef]

66. Cherian, S.; Potdar, V.; Jadhav, S.; Yadav, P.; Gupta, N.; Das, M.; Rakshit, P.; Singh, S.; Abraham, P.; Panda, S.; et al. SARS-CoV-2 Spike Mutations, L452R, T478K, E484Q and P681R, in the Second Wave of COVID-19 in Maharashtra, India. Microorganisms 2021, 9. [CrossRef] 
67. Planas, D.; Veyer, D.; Baidaliuk, A.; Staropoli, I.; Guivel-Benhassine, F.; Rajah, M.M.; Planchais, C.; Porrot, F.; Robillard, N.; Puech, J.; et al. Reduced sensitivity of SARS-CoV-2 variant Delta to antibody neutralization. Nature 2021, 596, 276-280. [CrossRef] [PubMed]

68. McCallum, M.; Walls, A.C.; Sprouse, K.R.; Bowen, J.E.; Rosen, L.; Dang, H.V.; deMarco, A.; Franko, N.; Tilles, S.W.; Logue, J.; et al Molecular basis of immune evasion by the delta and kappa SARS-CoV-2 variants. bioRxiv 2021, 2021.2008.2011.455956. [CrossRef]

69. Hodcroft, E. Variant: 21C (Epsilon). Available online: https:/ / covariants.org/variants/21C.Epsilon (accessed on 8 July 2021).

70. Sensoy, O.; Almeida, J.G.; Shabbir, J.; Moreira, I.S.; Morra, G. Chapter 16-Computational studies of G protein-coupled receptor complexes: Structure and dynamics. In Methods in Cell Biology; Shukla, A.K., Ed.; Academic Press: Cambridge, MA, USA, 2017; Volume 142, pp. 205-245.

71. NCBI-Virus. SARS-CoV-2 Data Hub. Available online: https://www.ncbi.nlm.nih.gov/labs/virus/vssi/\#/virus?VirusLineage_ ss $=$ Severe $\% 20$ acute $\% 20$ respiratory $\% 20$ syndrome $\% 20$ coronavirus $\% 202 \% 20$ (SARS-CoV-2), \%20taxid:2697049\&SeqType_s= Nucleotide\&Lineage_s=B.1.1.7 (accessed on 31 July 2021).

72. Petra, M.; Steven, K.; Mahesh Shanker, D.; Guido, P.; Bo, M.; Swapnil, M.; Charlie, W.; Thomas, M.; Isabella, F.; Rawlings, D.; et al. SARS-CoV-2 B.1.617.2 Delta variant emergence and vaccine breakthrough. Nat. Portf. 2021. [CrossRef] 